\title{
A REVIEW OF THE PRESENCE OF SOME FOOD CONTAMINANTS ON THE TERRITORY OF THE REPUBLIC OF SERBIA
}

Bojana Danilović ${ }^{\star}$, Velibor Potić, Sandra Stamenković, Dragiša Savić

Faculty of Technology, University of Niš, Leskovac, Serbia

Food contamination is one of the major problems in food distribution. Microorganisms and their metabolites are the most common food contaminants. This review consolidates the reported food contamination cases in the Republic of Serbia. Mycotoxins were stated as the most common contaminants in various foods. Among them mycotoxins like zearalenone, aflatoxins, fumonisins, and deoxynivalenol were the most frequently detected. Also, the contamination caused by the presence of various microorganisms like L. monocytogenes, E. coli, Salmonella spp. and S. aureus was reported in high frequency. The microbial contamination was usually detected in meat and dairy products. Although heavy metals were detected in some products, in most cases their concentrations were in accordance with the legislation. A higher level of $\mathrm{Pb}$ and $\mathrm{Hg}$ was stated only in a few samples of tea, milk and fish. The constant analysis, control and prevention are needed at all levels of the production in order to compile the safety requirements and international legislation.
(REVIEW PAPER)

UDC 614.31:615.9:547.67

Keywords: food contamination, microorganisms, mycotoxins, heavy metals

\section{Introduction}

The importance of food is crucial, so its safety represents an unconditional request made by both consumers and national and international legislation [1].

According to the Food safety law of the Republic of Serbia, food is considered unsafe for consumption if it contains [2]:

- Plant protection products, biocides, contaminants, their metabolites or reactive products in the amount higher than the maximum allowed concentration or if their use is not approved;

- Substances with the pharmacological effect i.e. their metabolites which are not allowed for animals used in the food industry;

- Substances with pharmacological effect or their metabolites in treated animals if the prescribed waiting period was not complied.

Also, food is not appropriate for the consumption if it is unacceptable for the intended use due to the contamination induced by an external factor, as well as putrefaction, deterioration or decay [2].

Foodstuffs can be contaminated in a variety of ways, primarily by the presence of microorganisms. In addition to the risk of the presence of microorganisms themselves, a great danger is their metabolites which can be highly toxic and harmful to the customer's health. Among them, mycotoxins are the most important hazard since they represent the increasing threat from the aspects of health and economy. Besides microbial contamination, food can be contaminated by heavy metals, pesticides and other hazards which can deteriorate the quality and the nutritive value of the food. Because of the fact that there is almost no food without harmful substances, a permanent risk analysis, identification and determination of the maximum allowed concentration in food is required [1].

Food safety is one of the most important issues since the concentrations of toxic substances in the environment are permanently increasing. The industrial use and other technological processes lead to the increase of the presence of heavy metals and other harmful matters in the atmosphere, water and soil [3].

To the authors' knowledge, there is little literature data about the collection and analysis of the reported cases of food contamination on the territory of the Republic of Serbia. For that cause, this paper reviews the cases of food contamination on the territory of the Republic of Serbia reported only in scientific papers in the past thirteen years.

\section{Bacterial contamination}

Foodstuff prepared mostly from natural components is a perfect habitat for the growth of various groups of microorganisms, so microbial contamination represents one of the most common types of food contamination. The growth and metabolites of some contaminant microorganisms and food borne pathogens can cause food spoilage and/or have harmful effects on human health.

The most common bacteria involved in food contamination are Salmonella spp., Campylobacter spp., Listeria monocytogenes, Escherichia coli, Staphylococcus aureus,

\footnotetext{
* Author address: Bojana Danilović, Faculty of Technology, University of Niš,

Bulevar Oslobodjenja 124, 16000 Leskovac, Serbia

E-mail: danilovic@tf.ni.ac.rs

The manuscript received: July, 3, 2017.

Paper accepted: November, 17, 2017.
} 
Clostridium botulinum, Clostridium perfrigens, and Bacillus cereus [4-7].

\section{Staphylococcus spp.}

The great risk of contamination of food induced by staphylococci is related to the production of enterotoxins. The ability to produce toxins depends on the staphylococci strain and the type of the food product. The constitution of the food matrix can favour or suppress the growth of a particular enterotoxigenic type of staphylococci [8].

About 20 types of staphylococcal enterotoxins have been investigated so far. The most common producer of enterotoxins is St. aureus. This species can get into food from the surroundings, hands of the producers or from the animal itself. It usually contaminates meat, milk or dairy products since the conditions that prevailed in these foods are suitable for the growth of St. aureus [9]. The infections caused by St. aureus represent a growing medical problem as they became very frequent and strains are often resistant to antimicrobial drugs [10].

St.aureus is a Gramm positive bacterium with the optimal temperature range $30-37^{\circ} \mathrm{C}$. Also, it is resistant to low temperatures, but it can be destroyed by pasteurisation[11]. Due to the production of carotenoids, the colonies have a golden colour. As many other staphylococci, these bacteria are resistant to penicillin, but they can also be resistant to tetracycline, streptomycin, erythromycin and gentamicin [12].

The pathogenic effect of St. aureus relies on the production of the large number of enzymes and toxins, so the intoxications are mostly caused by the consumption of food with the presence of enterotoxins [10]. Because of a high risk of contamination and intoxication, there is a need for permanent control and monitoring of the presence of St. aureus in food.

In one investigation conducted in Serbia (Table 1) 25 samples of dairy products and 10 samples of fresh meat were investigated for the presence of staphylococci and staphylococcal enterotoxins. The results were positive for the presence of St. aureus in 2 of 5 samples of cheese and ice cream and 3 of 10 samples of meat, while staphylococcal enterotoxins were observed only in ice cream [9]. The analyses of 5 types of fish which are most common on the Serbian market have shown that all the analysed samples were negative for the presence of this bacterium [13]. On the other hand, among 60 samples of cheeses, coagulase positive staphylococci were identified in $50 \%$ of the samples. Additionally, the frequency of the isolation of staphylococci was higher in the samples collected during the summer period $(70 \%)$ compared to the samples collected in the winter period (30\%)[14].

\section{Listeria monocytogenes}

L. monocytogenes is a pathogenic bacterium which can cause listeriosis, a disease with a small percent of occurrence but a large mortality rate. In the Republic of Serbia, the legislative about the presence of Listeria spp. in food products was defined in 2010 . There are reports about lis- teriosis epidemic in the USA and Switzerland caused by the consummation of contaminated milk and dairy products $[15,16]$

L. monocytogenes is a Gram-positive, rod-shaped asporogenic bacterium [15]. The optimal temperature is in the range from $20-25^{\circ} \mathrm{C}$, but it can grow in the temperature range from $1-45^{\circ} \mathrm{C}$ [17]. Since this species can grow at low $\mathrm{pH}$ values, high concentrations of $\mathrm{NaCl}$ and low temperatures, permanent monitoring of the production process, packaging and storage is required in order to prevent the contamination $[15,18]$.

Raw materials of animal and plant origin represent one of the possible sources of contamination of minimally processed food. In recent years, more attention has been paid to the post-process contamination caused by the contact of the food products and contaminated surfaces of the production facilities. In the form of biofilm made on the surfaces, this bacteria can survive for months or even years [19].

The analysis of 100 samples of cow's milk collected from the dairies from South Serbia have shown that there were no samples contaminated with L. monocytogenes (Table 1), while $3 \%$ of the samples were contaminated with L. innocua [17]. In another study [20] from 29 samples of fresh chicken, pork and beef meat collected from the markets in Novi Sad, $83 \%$ of the samples were positive for Listeria spp. The highest frequency of isolation was observed in pork samples $(90 \%)$ while the frequencies of isolation for chicken and beef samples were $80 \%$ and $78 \%$, respectively. Among Listeria species, L. monocytogenes was most dominant with $30 \%$ of the isolates from pork and chicken meat and $22 \%$ of isolates from beef meat [20].

The representatives of the Listeria spp. were also identified in $12 \%$ of 470 samples of fresh, frozen, salted, smoked and thermally processed fish and seafood. In this investigation, L. monocytogenes was present in $2 \%$ of the samples [21].

\section{Escherichia coli}

E. coli is a Gram-negative rod shaped bacteria from the family Enterobacteriaceae [22]. E. coli is frequently isolated bacterium from human and animal intestine. Some E. coli serotypes can be pathogenic since they can produce enterotoxin (LT), verotoxin (VT), haemolysin (HLy) and cytotoxic necrotizing factor (CNF) [23, 24]. According to Rhoades et al. [25] the predominant serogroups which can cause verocytotoxigenic associated illness are O45, O26, O91, O103, 0111, 0121, 0145 and O157. Infections in humans in the bottom line can lead to a haemolytic uremic syndrome and thrombocytopenic purpura [22]. The first report about the infection caused by $E$. coli $\mathrm{O} 157$ on the territory of the Republic of Serbia was recorded in 2002 [26]. At that time, this infection was already dominant in developed countries like the USA, Canada, the UK, Australia, Belgium, Germany and Japan [27].

According to the research conducted on the farms and individual households on the territory of Serbia, verocytotoxigenic $E$. coli was observed in 431 of 2660 samples of animal's faeces (Table 1) [22]. Also, the investigation of the 
samples of cheeses collected from the open markets in Pančevo, Belgrade and Subotica showed that $69 \%$ were positive for the presence of $E$. coli while none of them was verocytotoxigenic [28]. The analyses of 910 samples of ewe's milk showed that $21 \%$ of the samples were positive for the presence of E.coli [29].

\section{Salmonella spp.}

Salmonella spp. also belongs to the family Enterobacteriaceae. The genus includes over 2,570 serotypes and all species are pathogenic to humans [30]. Among them, the main problem is probably the presence of Salmonella typhimurium and Salmonella paratyphimurium which can cause systemic fevers that can be fatal without therapy [25]. Be- sides these serotypes, Salmonella enterica subsp. enterica serotype Enteritidis (S. enteritidis), S. infantis and S. hadar can cause salmonelosis in humans [31]. Salmonella spp. are capable of growth in the temperature range from $7-49.5$ ${ }^{\circ} \mathrm{C}$, but can also survive a long period under chilled or frozen storage [25]. It is usually associated with eggs, meat and meat products. The investigation of Kalaba [30] showed that the presence of Salmonella spp. in 234 samples of the frozen chicken neck skin was almost $9 \%$. On the other hand, Salmonella spp. was not isolated from the fish meat samples [13]. The analysis of 300 samples of meat from the producers in Serbia indicated the presence of Salmonella in 25 samples, mostly in minced meat (Table 1) [32].

Table 1. Cases of contamination caused by microorganisms reported in the Republic of Serbia

\begin{tabular}{|c|c|c|c|c|}
\hline Food & Microorganism & Contaminant & $\begin{array}{l}\text { Frequency of } \\
\text { isolation, \% }\end{array}$ & Reference \\
\hline $\begin{array}{l}\text { Homemade } \\
\text { cheese }\end{array}$ & St. aureus & $\begin{array}{l}\text { Staphylococcal } \\
\text { enterotoxins }\end{array}$ & 40 & [9] \\
\hline Ice-cream & St.aureus & $\begin{array}{l}\text { Staphylococcal } \\
\text { enterotoxins }\end{array}$ & 40 & [9] \\
\hline Fresh meat & St.aureus & $\begin{array}{l}\text { Staphylococcal } \\
\text { enterotoxins }\end{array}$ & 30 & [9] \\
\hline Cheese & St.aureus & $\begin{array}{l}\text { Staphylococcal } \\
\text { enterotoxins }\end{array}$ & 50 & [14] \\
\hline Fresh ewe's milk & St.aureus & $\begin{array}{l}\text { Staphylococcal } \\
\text { enterotoxins }\end{array}$ & 18.9 & [29] \\
\hline $\begin{array}{c}\text { Fresh chicken } \\
\text { meat }\end{array}$ & L.monocytogenes & $\begin{array}{l}\text { Microorganism } \\
\text { itself }\end{array}$ & 30 & [20] \\
\hline Fresh pork meat & L.monocytogenes & $\begin{array}{l}\text { Microorganism } \\
\text { itself }\end{array}$ & 30 & [20] \\
\hline Fresh beef & L.monocytogenes & $\begin{array}{l}\text { Microorganism } \\
\text { itself }\end{array}$ & 22.2 & [20] \\
\hline Fresh fish & L.monocytogenes & $\begin{array}{l}\text { Microorganism } \\
\text { itself }\end{array}$ & 2.3 & [21] \\
\hline Seafood & L.monocytogenes & $\begin{array}{l}\text { Microorganism } \\
\text { itself }\end{array}$ & 12.3 & [21] \\
\hline $\begin{array}{l}\text { Homemade } \\
\text { cheese }\end{array}$ & E. coli & $\begin{array}{c}\text { Microorganism } \\
\text { itself }\end{array}$ & 69 & [28] \\
\hline Fresh ewe's milk & E. coli & $\begin{array}{l}\text { Microorganism } \\
\text { itself }\end{array}$ & 20.8 & [29] \\
\hline Fresh ewe's milk & Micrococcus spp. & $\begin{array}{l}\text { Microorganism } \\
\text { itself }\end{array}$ & 20.4 & [29] \\
\hline Minced meat & Salmonella spp. & $\begin{array}{l}\text { Microorganism } \\
\text { itself }\end{array}$ & 18 & [32] \\
\hline $\begin{array}{c}\text { Meat } \\
\text { preparations }\end{array}$ & Salmonella spp. & $\begin{array}{l}\text { Microorganism } \\
\text { itself }\end{array}$ & 7 & [32] \\
\hline
\end{tabular}

\section{Bacillus cereus}

$B$. cereus is the Gram-positive, spore-forming bacterium which can be isolated from soil, dust and plants [33]. $B$. cereus spores are resistant to high temperature, the low presence of water, gastric acid and other physical stresses. Additionally, B. cereus can form two types of toxins (thermostable and thermolabil toxin) which can cause severe problems in human health [34]. It is an opportunistic human pathogen often found in foods like dairy products, spices, vegetables. The analysis of 200 samples of goat milk did not indicate the presence of $B$. cereus [35]. The same results were reported for the starter dough used for the production of Pirot's bread [36].

Mycotoxin contamination

Moulds can be frequently found as food contaminants. 
Species belonging to genera Aspergillus, Penicillium and Eurotium are called storage moulds because they can grow with a water activity value lower than 0.85 . They are often isolated from spices, dried fruit, vegetables, sunflower seed and similar products. Fusarium and Alternaria species are field moulds and they require higher moisture content and lower temperature, so they can be found on cereals. In the last 50 years, a lot of attention has been paid to the presence of moulds in food because of their ability to produce harmful mycotoxins. Mycotoxins are synthesised from a great number of biochemically simpler intermediates of primary metabolism with the involvement of different enzymes [37].

Mycotoxins are toxic products of secondary metabolism of filamentous fungi [38]. After the production, they diffuse into the substrate so it is not possible to remove them by a simple removal of the moulds from the surface of the substrate. These organic compounds can have very different structures, while the size is in the range from 200 to $700 \mathrm{Da}$. They are lipid soluble so they can accumulate in lipid parts of the plants and animals [39]. The production of mycotoxins can start in the infected plant in the field and continue after the harvest, or can be initiated during the storage of the products [40]. They can accumulate in the muscles or liver of the animals after the consummation of contaminated plants so they can reach the human body through the food of plant or animal origin [37, 39]

The consequences of the presence of mycotoxins in food can be manifested through animal death, yield decrease, reduced reproductivity, changes in the sensory characteristics of the food and finally, through different intoxications and liver disorders in humans [37, 39]. Some mycotoxins can be related to certain types of cancer [41].

Among about 400 different mycotoxins which have been described so far, the most important are aflatoxin, ochratoxin A, citrinin, ergot alkaloids, fumonisins, patulin, trichothecenes, and zearalenone [39, 42, 43]. The main strategy for preventing the occurrence of mycotoxins in food is the inhibition of the moulds mycotoxin producers. Also, different hygienic measures and fast and specific methods for determination of the mould growth are needed in order to prevent the contamination of food [44].

Aflatoxins

Aflatoxins are the most investigated mycotoxins because of their high toxic and cancerogenic effect. Aflatoxins are very harmful to humans since they can induce cancer and liver damage or children's physical and psychical disorders [39]. They are produced by the species Aspergillus flavus, $A$. bombycus, $A$. parasiticus, $A$. nomius, $A$. ochraceoroseus, A. tamarrii, A. pseudotamarii, A. parvisclerotigenus and $A$. rambellii [45-47]. These species can grow on a variety of substrates as oilseeds, cereals and cereal products, stone fruits, tropical fruits and spices. They are usually found in the products with high moisture content or during the storage at high temperatures. The most important aflatoxins are aflatoxin $B_{1}, B_{2}, G_{1}, G_{2}, M_{1}$ and $M_{2}$ [48]. Aflatoxin B1 can be characterized as the most toxic since it is a mutagen, and has a teratogenic and cancerogenic effect. It can be classified as the first category of the human cancerogenic materials [49]. After the consummation of aflatoxin-contaminated feeds, aflatoxin B1 is being metabolically transformed into a hydroxylated form aflatoxin M1 [42]. This form can be detected in milk after the ingestion of feed contaminated with aflatoxin B1 [50]. Compared to aflatoxin B1, aflatoxin M1 has approximately a ten times lower cancerogenic effect [49]. The maximum allowed concentration of aflatoxin M1 in milk in the Republic of Serbia at the moment is $0.250 \mu \mathrm{g} / \mathrm{kg}$, while in the past this value was $0.5 \mu \mathrm{g} / \mathrm{kg}$.

In one investigation [51], 65 different commercial samples of milk including 34 samples of pasteurised and 31 samples of long-term milk were collected from local markets. The results showed that 18 samples of milk (7 samples of pasteurised milk and 11 samples of long-term milk) were positive for the presence of aflatoxin M1 (Table 3). Concentrations of aflatoxins were lower than the maximum value regulated by the Serbian law and EU legislative.

Similar research [52] included 23 samples of fresh farm milk and 67 samples of the processed milk from local markets. The samples of fresh cows', ewes' and goats' milk were collected from small individual farms. Among them, 7 samples were contaminated with aflatoxin $M 1$ in concentrations higher than defined by EU legislative but in accordance with the limit value regulated by the former Serbian low. On the other hand, 18 samples of commercial milk were contaminated in the concentrations lower than marginal values defined by the Regulation on the quantities of pesticide, metals, metalloids and other toxic substances, drugs, anabolic and other substances that could be found in foods in Serbia [2].

The analysis of the samples of baby food, rye, oat and maize collected from the Serbian market showed negative results [53]. On the other hand, the samples of barley, soybean and mixed cereals were positive for the presence of aflatoxin, although in accordance with the maximum allowed concentrations. According to the legislation, this concentration is $5 \mu \mathrm{g} / \mathrm{kg}$ [2].

\section{Ochratoxin A}

Ochratoxin $A$ is the most important secondary metabolite of the moulds belonging to the genera Aspergillus ( $A$. niger, $A$. ochraceus, $A$. carbonarius, $A$. westerdijikiae, $A$. steynii) and Penicillium ( $P$. verrucosum and $P$. nordicum) $[43,54]$. P. verrucosum, $P$. nordicum and $A$. ochraceus can produce ochratoxin $A$ when they grow on the surface of sausages, ham and other meat products. A. niger can produce ochratoxin $A$ in wine and grape. According to the International Agency for Research of Cancer (IARC) this mycotoxin belongs to the group 2B of possible carcinogens. Also, it may have teratogenic, neurotoxic, genotoxic, immunotoxic and nefrotoxic effects [55].

Ochratoxin A was detected in $20.2 \%$ of the samples of melted cheese collected from Serbian markets and 60\% of the samples of healthy food: corn, wheat, oats, rice and dry grapes (Table 3) [56]. The concentration of ochratoxin in food products defined by the legislation is $10 \mu \mathrm{g} / \mathrm{kg}$ [2]. 


\section{Fusariotoxins}

Fusariotoxins are the product of the metabolism of moulds Fusarium spp. Among 61 species belonging to this genus, 35 species can produce 137 different mycotoxins. Trichotecens are most frequent and represent $58 \%$ of produced mycotoxins. Three most significant producers are $F$. sporotrichioides which produce T-2 toxin and deoxinivalenon, $F$. graminearum produces zearalenone and deoksinivalenon and $F$. verticillioides produce fumonisins [37].

\section{Fumonisins}

Fumonisins represent a group of 15 mycotoxins with three very harmful for humans and animals: fumonisin B1, B2 and B3 [57]. The above mentioned fumonisins are most common while fumonisin B1 is usually present in the highest concentration [40]. Fumonisin is constituted of two hydrophilic chains connected with ester bonds to one aliphatic chain with $20 \mathrm{C}$ atoms. It is usually produced by $F$. vertialliaides, F. moniliforme and $F$. proliferatium $[40,49,58]$ and in smaller percent by $A$. niger [59].

Toxicity of fumonisin is in the ability to disturb the synthesis of sphingolipids which are the main component of the cell membrane. This can induce different disorders in the cell function. As the result, gullet cancer or nervous system damage can occur, so the IARC classified them as potential carcinogens [60].

A research performed in Serbia [57] included 203 samples of maize, 180 samples of winter wheat and 120 samples of winter barley. Fumonisin B1 was detected in 144 samples of maize, 109 samples of wheat and 41 samples of barley which represents 72,61 and $34 \%$ of the samples, respectively (Table 2).

Table 2. Overview of the food contamination caused by mycotoxins in the Republic of Serbia

\begin{tabular}{|c|c|c|c|c|}
\hline Food & Microorganism & Contaminant & $\begin{array}{c}\text { Frequency of } \\
\text { contamination, } \\
\%\end{array}$ & Reference \\
\hline Maize & Fusarium spp. & Fumonisin B1 & 70.9 & [57] \\
\hline Barley & Fusarium spp. & Fumonisin B1 & 34 & [57] \\
\hline Wheat & Fusarium spp. & Fumonisin B1 & 0.6 & [57] \\
\hline Wheat & Fusarium spp. & Fumonisin B1 & 85 & [61] \\
\hline Wheat from Banat area & Fusarium spp. & Fumonisin & 53.3 & [76] \\
\hline Wheat from Bačka area & Fusarium spp. & Fumonisin & 40 & [76] \\
\hline Wheat from Srem area & Fusarium spp. & Fumonisin & 60 & [76] \\
\hline Wheat & F. graminearum & Zearalenone & 64.5 & [76] \\
\hline Wheat from Banat area & Fusarium spp. & Zearalenone & 53.3 & [76] \\
\hline $\begin{array}{l}\text { Wheat from } \\
\text { Bačka area }\end{array}$ & Fusarium spp. & Zearalenone & 40 & [76] \\
\hline $\begin{array}{l}\text { Wheat } \\
\text { Srem area }\end{array}$ & Fusarium spp. & Zearalenone & 93.3 & [76] \\
\hline Maize (Vojvodina 2004) & F. graminearum & DON & 50 & [71] \\
\hline Maize (Vojvodina 2005) & F. graminearum & DON & 42.1 & [71] \\
\hline Maize (Vojvodina 2006) & F. graminearum & DON & 41.2 & [71] \\
\hline Wheat from Banat area & Fusarium sp. & DON & 53.3 & [76] \\
\hline Wheat from Bačka area & Fusarium $s p$. & DON & 20 & [76] \\
\hline Wheat Srem area & Fusarium spp. & DON & 100 & [76] \\
\hline Wheat & Fusariumspp. & DON & 73 & [61] \\
\hline Wheat & Fusarium spp. & T-2 toxin & 90.2 & [61] \\
\hline Milk & Aspergillus spp. & Aflatoxin M1 & 25. & [51] \\
\hline $\begin{array}{l}\text { Fresh milk (individual } \\
\text { households) }\end{array}$ & Aspergillus spp. & Aflatoxin M1 & 30.4 & [52] \\
\hline $\begin{array}{l}\text { Commercial milk } \\
\text { samples }\end{array}$ & Aspergillus spp. & Aflatoxin M1 & 29.8 & [52] \\
\hline $\begin{array}{l}\text { Rice flakes and } \\
\text { expanded rice }\end{array}$ & $\begin{array}{c}\text { A. flavus } \\
\text { A. parasiticus }\end{array}$ & Aflatoxins & 33.3 & [53] \\
\hline $\begin{array}{l}\text { Barley flakes and } \\
\text { expanded barley }\end{array}$ & $\begin{array}{c}\text { A.flavus } \\
\text { A. parasiticus }\end{array}$ & Aflatoxins & 50 & [53] \\
\hline
\end{tabular}


Table 2 (continued)

\begin{tabular}{|c|c|c|c|c|}
\hline Food & Microorganism & Contaminant & $\begin{array}{c}\text { Frequency of } \\
\text { contamination, } \\
\%\end{array}$ & Reference \\
\hline $\begin{array}{l}\text { Wheat flakes, } \\
\text { expanded wheat and } \\
\text { grits }\end{array}$ & $\begin{array}{l}\text { A. flavus } \\
\text { A.parasiticus }\end{array}$ & Aflatoxins & 16.6 & [53] \\
\hline Soya flakes & $\begin{array}{l}\text { A. flavus } \\
\text { A.parasiticus }\end{array}$ & Aflatoxins & 66.6 & [53] \\
\hline Buckwheat & $\begin{array}{l}\text { A. flavus } \\
\text { A.parasiticus }\end{array}$ & Aflatoxins & 100 & [53] \\
\hline Mixed cereals & $\begin{array}{l}\text { A. flavus } \\
\text { A.parasiticus }\end{array}$ & Aflatoxins & 63.6 & [53] \\
\hline Cheese & $\begin{array}{l}\text { Aspergillus spp., } \\
\text { Penicillium spp. }\end{array}$ & Ochratoxin A & 19.5 & [56] \\
\hline Fermented sausages & $\begin{array}{l}\text { Aspergillus spp., } \\
\text { Penicillium spp. }\end{array}$ & Ochratoxin A & 33.3 & [56] \\
\hline \multirow{8}{*}{ Pastry products } & & & 5.8 & \multirow{8}{*}{ [48] } \\
\hline & & & 44.4 & \\
\hline & $\begin{array}{c}\text { Acremonium spp. } \\
\text { Alternaria spp. } \\
\text { Aspergillus spp. } \\
\text { Cladosporium spp. }\end{array}$ & & $\begin{array}{l}52.9 \\
23.5\end{array}$ & \\
\hline & $\begin{array}{l}\text { Eurotium spp. } \\
\text { Fusarium spp. } \\
\text { Mucor spp. }\end{array}$ & Mycotoxins & $\begin{array}{c}23.5 \\
47\end{array}$ & \\
\hline & $\begin{array}{l}\text { Phialophora spp. } \\
\text { Penicillium spp. }\end{array}$ & & 17.6 & \\
\hline & Ulocladium spp. & & 5.8 & \\
\hline & & & 76.5 & \\
\hline & & & 5.8 & \\
\hline $\begin{array}{l}\text { Fresh salad made from } \\
\text { different vegetables }\end{array}$ & $\begin{array}{l}\text { Alternaria alternata } \\
\text { A. niger }\end{array}$ & Mycotoxins & $\begin{array}{l}6.9 \\
10\end{array}$ & [77] \\
\hline
\end{tabular}

Also, $85.4 \%$ of wheat samples collected in Serbia during 2010. was positive for fumonisin B1 [61]. To compare, in neighbouring Croatia the frequency of isolation of Fusarium spp. was $5-69 \%$ for wheat, $25-100 \%$ for maize, $4-17 \%$ for soybean and $3-17 \%$ for pea samples [62]. Additionally, the most dominant species were $F$. graminearum on wheat (27\%), F. verticillioides on maize (83\%), F. sporotrichioides on soybean (34\%) and F. proliferatum on pea (29\%).

\section{Patulin}

Patulin is a secondary metabolite of some species of Penicillium and Aspergillus genera [48]. Some of them are $P$. expansum, P. griseofulvum [63], A. clavatus, A. giganteus and $A$. terreus [64].

Patulin can be found in fruits and vegetables, mostly apples, pears, strawberries, mango, apricots, grapes, bananas and tomatoes. The presence of this toxin in the product is a consequence of the use of rotten fruits in the production process. This is a main mycotoxin in fruits and the maximum allowed concentration in most countries, including the Republic of Serbia, is $50 \mathrm{mg} / \mathrm{kg}$ [65]. It is classified as the third group of carcinogens. Patulin can be produced in the temperature range $0{ }^{\circ} \mathrm{C}$ do $25^{\circ} \mathrm{C}$ and $\mathrm{pH}$ range $3.2-$ 3.8. Also, it is stable on the temperature of pasteurisation, so it can often be isolated from apple juice. According to some researches, the concentration of patulin can be reduced by the use of centrifugation, benthonic filtration and the enzymatic treatment [48].

\section{Deoxynivalenol (DON)}

Deoxynivalenol (DON) belongs to the trichothecenes family of mycotoxins. It is a polar organic compound of the type B trichothecenes [66]. It is usually produced by Fusarium culmorum and Fusarium graminearum [67].The contamination of economically important cereals represents a great problem in Europe, Asia and America since it occurs in the field more frequently than in the warehouse [68]. Since this mycotoxin is stable during the production process, it can often be found in processed food. The maximum allowed daily intake of DON is $1 \mathrm{mg} / \mathrm{kg}$ body weight [69].

A few studies claimed that the presence of DON in food can cause serious health issues, especially anorexia and vomiting [68]. DON is less toxic than other trichothecenes, for example T-2, but in higher concentrations it can cause shock and eventually death. A prolonged intake of small quantities of DON leads to weight loss, anorexia and loss of appetite [70]. 
The research conducted in Vojvodina in the period from 2004-2006 indicated that the frequency of contamination of maize with DON was in the range of $40-50 \%$ while only $3 \%$ of the samples exceeded the maximum allowed concentration of $1 \mu \mathrm{g} / \mathrm{g}$ [64]. Similar results were obtained for wheat and sunflower seed, while the frequency of contamination of soybean was lower than $10 \%$ [71].

\section{T-2 toxin}

Toxin T-2 belongs to trichothecenes and it is produced by Fusarium spp. It is responsible for the inhibition of the synthesis of proteins and DNA synthetase in eukaryotic cells [72]. T-2 is usually present in the cereals like oats, barley and wheat [73]. The investigation [61] of wheat grains collected from seven localities in Serbia showed that $90.2 \%$ of the samples were positive for the presence of T-2 toxin.

\section{Zearalenone}

Zearalenone (ZEA or toxin F-2) is nonsteroidal estrogenic mycotoxin which is produced by different species of genus Fusarium: F. graminearum, F. culmorum, F. cerealis, $F$. equiseti, F. crookwellense and F. semitectum [74]. It can usually be found as the contaminant of the wheat or maize $[74,75]$. After the ingestion, ZEA can bond to estrogens receptors and induce morphological and functional changes in the reproductive system [75]. The concentration of zearalenon in grain samples allowed by Serbian low is $1 \mu \mathrm{g} /$ $\mathrm{kg}$ [2].

The investigation of the contamination of wheat in three regions of southern Serbia: Srem, Bačka and Banat have shown that the highest number of the samples contaminated with ZEA, DON and fumonisin was in the area of Srem (Table 2) [76]. In the same research, 7 samples had the concentrations of ZEA higher than the maximum allowed value in EU.

\section{Heavy metals and pesticides contamination}

Heavy metals are one of the greatest risks in food safety. Mercury $(\mathrm{Hg})$, lead $(\mathrm{Pb})$, cadmium $(\mathrm{Cd})$, iron (Fe), zinc $(\mathrm{Zn})$, arsenic (As) and copper $(\mathrm{Cu})$ are the most common contaminants. They get into plants through the contaminated environment, soil, water and air [78].

$\mathrm{Pb}$ and $\mathrm{Cd}$ concentrations in milk are very important from the aspect of the food safety because of a high risk for the human health. The heavy metal concentration in cow's milk and blood can be considered as a bio-indicator of the contamination of the environment. On the other hand, low concentrations of $\mathrm{Pb}$ and $\mathrm{Cd}$ in milk are not the proof of the low concentration in soil because the absorption of heavy metals by plants depends on the $\mathrm{pH}$ value of the soil. Plants can intake heavy metals from acidic soils easier [79].

Lead can incorporate into the body, especially through the the respiratory and digestive tract. The main way of contamination is through the consumption of contaminated food and water [80]. Lead poisoning affects the function of the brain and nervous system, reduces the level of intelligence, observation and memory. In some cases lead poisoning can cause death [1]

Mercury in food usually originates from the use of pesticides. It can also be used in cosmetics to reduce the growth of bacteria or can be made as a product of burning coal [1]. Mercury is toxic as an elementary form or in all its compounds. Its toxicity depends on the chemical form and the most toxic are organic mercury compounds [81]. The symptoms of poisoning occur in digestive organs, and then in the nervous system. The intake of pectin and alginate can reduce the absorption of mercury.

Cadmium belongs to a group of toxic heavy metals. Most foods contain traces of $\mathrm{Cd}$, but higher amounts can be found in shellfish, mushrooms, and some plants (cocoa, rice). Cadmium is deposited in the liver, kidneys and bones, with a half-life in the body of 20 years. Higher concentrations of $\mathrm{Cd}$ can cause bone disorders - osteoporosis, spontaneous fractures, severe pain in bones, partly because of the renal dysfunction caused by $\mathrm{Cd}$ and partly due to the effects of $\mathrm{Cd}$ on $\mathrm{Ca}$ metabolism (increased elimination of $\mathrm{Ca}$ ), vitamin D metabolism disorders and disruption of collagen synthesis in bone cells [82].

Arsenic accumulates in the body, especially in hair, skin and some internal organs. Arsenic poisoning causes hair loss, dermatitis and problems with digestive organs, then fatigue, headache, confusion, psychological problems and certain changes in liver and kidneys [1].

Toxic matters are present in our environment and the industrial use of metals and certain technological processes lead to the increase of the concentrations of heavy metal and other harmful substances in the water, air and soil [3]. Also the environment can be contaminated with pesticides used in agriculture for the suppression of pests, weeds and plant diseases. These harmful substances can contaminate food and get transferred into the human organism where they induce acute and chronic health problems $[83,84]$.

The use of organochlorine pesticides for the suppression of pests and plant diseases is widely spread. The most important representatives are DDT (dichlorodiphenyltrichloroethane), $\mathrm{HCH}$ (hexachlorocyclohexane), endosulfan, aldrin, chlordine, dieldrin, heptachlor, mirex, HCB (hexachlorobenzene) and toxafen. Organochlorine pesticides belong to organic compounds which are very stable with the halftime of decomposition from a few months up to a few years or even few decades. For example, it is estimated that 4-30 years are needed for the degradation of DDT in soil, while other organochlorine pesticides can remain stable in soil for a long period of time. These pesticides are liposoluble compounds which accumulate in milk, blood and animal fat tissues. The use of contaminated food can induce them into the human organism where they can cause poisoning. Because of the high mortality rate caused by DDT and $\mathrm{HCH}$ poisoning, their use is forbidden or restricted in many countries [83].

In the investigation of different fish species from the 
Danube (asp, bream, barbel, carp, sturgeon, and pike) the concentration of organochlorine pesticides in the samples of asp and barbell was higher than allowed. Mercury was detected above the maximum value only in the fillets of asp (Table 3) [85].

Jankovic et al. [86] tested 651 sample, among them 350 samples of marine fish (hake, mackerel, sardines, grouper, sea bream and salmon), 34 samples of freshwater fish (carp and trout) and 267 samples of canned fish (tuna, pilchard) (Table 3). The mercury content in marine fish ranged from 0.005 to $0.208 \mu \mathrm{g} / \mathrm{g}$ (mean value $0.040 \mu \mathrm{g} / \mathrm{g}$ ); in freshwater fish from 0.005 to 0.099 $\mu \mathrm{g} / \mathrm{g}$ (mean value $0.020 \mu \mathrm{g} / \mathrm{g}$ ), while in the conserved fish products the mercury content ranged from 0.005 to $0.642 \mu \mathrm{g} / \mathrm{g}$ (mean value $0.064 \mu \mathrm{g} / \mathrm{g}$ ). The level of mercury in all samples was below the maximum allowed values determined by relevant EU legislation, as well as national regulations [86].
The analyses of the milk samples from three dairy farms located close to major roads and from two farms located in rural areas of Serbia for the presence of $Z n$, $\mathrm{Cu}, \mathrm{Fe}, \mathrm{Cd}$ and $\mathrm{Pb}$ showed that their concentrations were in compliance with the legislation in 4 of 5 samples (Table 3) [79].

The research conducted during 2011-2012 [82] included a total number of 10720 food samples: 2299 samples of fruits and fruit products, 2202 samples of vegetables and vegetable products, 1407 samples of cereals and cereal products, 1722 samples of meat and meat products, 1629 samples of fish and fish products, 929 samples of milk and dairy products, 63 samples of eggs and egg products and 469 samples of coffee, cocoa and tea. All analysed samples contained cadmium below the maximum allowed level of $0.5 \mathrm{mg} / \mathrm{kg}$ specified by national regulations (Table 3 ).

Table 3.Presence of heavy metals in food samples in the Republic of Serbia

\begin{tabular}{|c|c|c|c|}
\hline Food & Contaminant & Contamination & Reference \\
\hline Danube fishes & $\mathrm{Hg}, \mathrm{Pb}, \mathrm{Cd}$ & $\begin{array}{l}17 \% \text { contaminated } \\
\text { with } \mathrm{Hg}\end{array}$ & [87] \\
\hline $\begin{array}{l}\text { Spices (oregano, basil, } \\
\text { parsley and celery) }\end{array}$ & As, $\mathrm{Hg}, \mathrm{Pb}$ & $\begin{array}{l}\text { Concentration in } \\
\text { compliance with } \\
\text { national legislation }\end{array}$ & {$[80]$} \\
\hline Raw milk from farms & $\mathrm{Zn}, \mathrm{Cu}, \mathrm{Fe}, \mathrm{Cd}, \mathrm{Pb}$ & $\begin{array}{l}20 \% \text { contaminated } \\
\text { with } \mathrm{Pb}\end{array}$ & [79] \\
\hline $\begin{array}{l}\text { Wild poppy, oregano, } \\
\text { primrose, Rtanj tea and } \\
\text { marigold }\end{array}$ & $\mathrm{Fe}, \mathrm{Zn}, \mathrm{Cu}, \mathrm{Mn}$ & $\begin{array}{l}\text { Concentration in } \\
\text { compliance with } \\
\text { national legislation }\end{array}$ & [89] \\
\hline $\begin{array}{l}\text { Tea samples from the } \\
\text { market }\end{array}$ & $\mathrm{Cu}, \mathrm{Zn}, \mathrm{Mn}, \mathrm{Ni}, \mathrm{Pb}$ & $\begin{array}{l}25 \% \text { contaminated } \\
\text { with } \mathrm{Pb}\end{array}$ & [88] \\
\hline $\begin{array}{l}\text { Marine fish, freshwater } \\
\text { fish and canned fish } \\
\text { from the market }\end{array}$ & $\mathrm{Hg}$ & $\begin{array}{l}\text { Concentration in } \\
\text { compliance with } \\
\text { national legislation }\end{array}$ & {$[86]$} \\
\hline $\begin{array}{l}\text { Fruits, fruit products, } \\
\text { vegetables, vegetable } \\
\text { products, cereals, } \\
\text { cereal products, meat, } \\
\text { meat products, fish, fish } \\
\text { products, milk, dairy } \\
\text { products, eggs, egg } \\
\text { products, coffee, cocoa } \\
\text { and tea. }\end{array}$ & $\mathrm{Cd}$ & $\begin{array}{l}\text { Concentration in } \\
\text { compliance with } \\
\text { national legislation }\end{array}$ & [82] \\
\hline Apples Idared & As, $\mathrm{Pb}, \mathrm{Cd}, \mathrm{Hg}$ & $\begin{array}{l}\text { Concentration in } \\
\text { compliance with } \\
\text { national legislation }\end{array}$ & [3] \\
\hline
\end{tabular}

The paper of Milinković et al. [3] reported the content of heavy metals ( $\mathrm{As}, \mathrm{Pb}, \mathrm{Cd}$ and $\mathrm{Hg}$ ) and harmful substances (nitrate and nitrite) in the Idared apple varieties, at various locations in the area of Čačak. Depending on the locality, the As content in the fruit was in the range $0.0035 \mathrm{mg} / \mathrm{kg}$ to $0.0071 \mathrm{mg} / \mathrm{kg}, \mathrm{Pb}$ was in the range $0.0035 \mathrm{mg} / \mathrm{kg}$ to $0.0807 \mathrm{mg} / \mathrm{kg}$, Cd than $0.0028 \mathrm{mg} / \mathrm{kg}$ to $0.0059 \mathrm{mg} / \mathrm{kg}$ and $\mathrm{Hg}$ from $0.0058 \mathrm{mg} / \mathrm{kg}$ to $0.0076 \mathrm{mg} /$ $\mathrm{kg}$. The content of nitrate and nitrite in all samples was less than $3 \mathrm{mg} / \mathrm{kg}$. The content of heavy metals, as well as the content of nitrates and nitrites was much lower than that defined in the legislation [3].

The concentrations of $\mathrm{As}, \mathrm{Hg}$ and $\mathrm{Pb}$ analysed in the spices from the Serbian market (oregano, basil, parsley and celery) (Table 3 ) were within the allowed values of $1 \mathrm{mg} / \mathrm{kg}$ for As and $2 \mathrm{mg} / \mathrm{kg}$ for $\mathrm{Pb}$ [87]. 
In similar research, 8 tea samples including Camellia sinensis L., black and green tea, Mentha piperita and Matricaria chamomilla were analysed for the presence of $\mathrm{Cu}, \mathrm{Zn}, \mathrm{Mn}, \mathrm{Ni}$ and $\mathrm{Pb}$ (Table 3). Among all investigated samples only in the samples of Mentha piperita the content of $\mathrm{Pb}$ was higher than maximum allowed 2 $\mathrm{mg} / \mathrm{kg}$ [88].

Also, the analysis of wild poppy, oregano, primrose, Rtanj tea and marigold for the presence of heavy metals indicated that $\mathrm{Ni}, \mathrm{Pb}, \mathrm{Cd}$ were not detected, while the concentrations of $\mathrm{Fe}, \mathrm{Zn}, \mathrm{Cu}, \mathrm{Mn}$ were in compliance with legislation [89].

\section{Histamine}

Histamine belongs to the group of biogenic amines and it is produced by microbial decarboxylation of the amino acid histidine [90]. It can often be found in fermented food, meat products, cheese and fish products [91-93]. In fresh fish, histamine can be found due to the presence of Gram-negative intestinal bacteria, while in wine, cheese or dry sausages it is produced by the Gram-positive bacteria [91,94]. High concentrations of histamine consumed with food can cause poisoning or allergic reactions, so the determination of its concentration in food is very important [93].

The analysis of the histamine content in 4 different groups of packed Atlantic mackerel from the fish market in Serbia [93] showed the presence of histamine in all samples, but below the level of $200 \mathrm{mg} / \mathrm{kg}$ which is defined by the legislation [2]. During the storage, the histamine level increased in all samples and the highest values were observed in vacuum packed fish [93]. Similarly, Smajlović et al. have analyzed the samples of various types of frozen fish and canned fish available at the markets in Bosnia and Herzegovina and stated that the concentrations of histamine were lower than $100 \mathrm{mg} / \mathrm{kg}$ [95]. The analysis of dry fermented sausages indicated that histamine was not detected during the fermentation of the Petrovac sausages [91]. On the other hand, during the fermentation of cabbage, different concentrations of histamine were stated but all of them were below the allowed value [92].

\section{Conclusion}

According to the available literature data, the most common cases of contamination in Serbia include the presence of mycotoxins. Additionally, the presence of contaminating microorganisms cannot be negligible. This paper emphasizes the fact that it is necessary to establish a permanent and functional system of monitoring of hazardous substances in foods and raw materials at different stages of the food production. The analysis, control and preventive measures should be established at all levels of the production in accordance with the safety requirements and international legislation.

\section{Acknowledgments}

This work was funded by the Ministry of Education, Science and Technological Development of the Republic of Serbia, grant No.: 31032

\section{References}

[1] M. Jašić, Food safety and human health, Proceedings of the First International Conference on Ecological safety in postmodern environment, Apeiron University, (2009) 6777

[2] Official gazette of the Republic of Serbia, No. 25/2010 and 28/2011, Food safety legislation

[3] M. Milinković, R. Miletić, B. Lalević, Sadržaj teških metala u plodovima jabuke sorte Idared u proizvodnim lokalitetima Čačanskog kraja, Voćarstvo 46 (2012) 99-105

[4] E. Carrasco, A. Morales-Rueda, R.M. Arcía-Gimeno, Cross-contamination and recontamination by Salmonella in foods: A review, Food Research International 45(2) (2012) 545-556

[5] J.A. Evans, S.L. Russell, C. James, J.E.L Corry, Microbial contamination of food refrigeration equipment, Journal of Food Engineering 62 (3) (2004) 225-232

[6] H.R. Tavakoli, M. Aghazadeh Meshgi N. Jonaidi Jafari, M. Izadi, R. Ranjbar, A.A. Imani Fooladi, A survey of traditional Iranian food products for contamination with toxigenic Clostridium botulinum, Journal of Infection and Public Health 2(2) (2009) 91-95

[7] P. Udompijitkul, M. Alnoman, M.R. Sarker, Inactivation strategy for Clostridium perfringens spores adhered to food contact surfaces, Food Microbiology 34(2) (2013) 328-336

[8] S. Lončarević, H.J. Jørgensen, A. Løvseth, T. Mathisen, L.M. Rørvik, Diversity of St. aureus enterotoxin types within single samples of raw milk and raw milk products, Journal of Applied Microbiology 98 (2005) 344-350

[9] B. Lakićević, V. Janković, D. Spirić, V. Matekalo-Sverak, R. Mitrović, B. Borović, T. Baltić, Utvrđivanje prisustva stafilokoknih enterotoksina u namirnicama animalnog porekla ELISA testom, Tehnologija mesa 53(1) (2012) 50-55

[10] G. Jovanović, D. Đurđević Milošević, Poređenje dejstva antibiotika i eteričnih ulja na rast bakterija St. aureus. In: Proceedings of XXIIlth Conference of Agronomist, Veterinarians and Technologist 15(3-4) (2009) 181-188

[11] N. Rajić-Savić, N. Lazarević, B. Krstić, M. Podunava, St. aureus contamination and the milk quality, Proceedings of XXI Conference of Agronomists, Veterinarians and Technologists 13(3-4) (2007) 65-70

[12] E. Lindberg, I.Adlerberth, A.E. Wold, Antibiotic resistance in Staphylococcus aureuscolonising the intestines of Swedish infants, Clinical Microbiology and Infections 10(10) (2004) 890-894

[13] M. Milijašević, J. Babić, Ž.M. Baltić, V. Đorđević, D. Spirić, S. Janković, A. Spirić, Parametri higijenske ispravnosti četri vrste riba koje su najzastupljenije na tržištu Srbije, Tehnologija mesa 53(2) (2012) 127-133

[14] V. Janković, V. Đorđević, B. Lakićević, B. Borović, B. Velebit, R. Mitrović, Determination of Staphylococcal enterotoxins in cheese by immunoenzyme assays, Archives of Biological Science 64(4) (2012) 1449-1454

[15] G. Popović, D. Đurđević Milošević, Prisustvo bakterija 
Listeria monocytogenes u namirnicama i prateći rizik za zdravlje potrošača,Proceedings of XXII Conference of Agronomists, Veterinarians and Technologists 14 (3-4) (2008) 151-159

[16] A. Kasalica, V. Vuković, A. Vranješ, N. Memiši, Listeria monocytogenes in milk and dairy products, Biotechnology and Animal Husbandry 27(3) (2011) 1067-1082

[17] D. Pešić Mikulec, N. Dugalić Vrndić, N. Rajić Savić, Novija iskustva u izolovanju Listeria spp. u mleku i proizvodima od mleka, Proceedings of XXIV Conference of Agronomists, Veterinarians and Technologists 16(3-4) (2010) 201-210

[18] M. Saludes, M. Troncoso, G. Figueroa, Presence of Listeria monocytogenes in Chilean food matrices, Food Control 50 (2015) 331-335

[19] D. Milanov, R. Ašanin, B. Vidić, D. Krnjaić, J. Petrović, S. Savić, Scanning electron microscopy of Listeria monocytogenes biofilms on stainless steel surface, Acta Veterinaria 59(4) (2009) 423-435

[20] G.R. Dimić, S.D. Kocić-Tanackov, O.O. Jovanov, D.D. Cvetković, S.L. Markov, A.S. Velićanski, Presence of Listeria species in fresh meats from retail markets in Serbia, Acta Periodica Technologica 41 (2010) 1-6

[21] J. Kuzmanović, R. Ašanin, M. Baltić, D. Mišić, M. Dimitrijević, M. Stojanović, N. Ašanin, I. Kovačević, Presence of Listeria spp. in fish samples, fish products and sea products, Acta Veterinaria 61(2-3) (2011) 193203

[22] A. Samokovlija, B. Đuričić, Escherichia coli-stari problem, nova patologija, Veterinarski glasnik 63(1-2) (2009) 113123

[23] V. Katić, L. Stojanović, The effect of salt concentration and $\mathrm{pH}$ on the survival and growth of E.coli O157:H7 in white cheese and trypticase soy broth, Acta Veterinaria53 (5-6) (2003) 411-418

[24] A. Hostacká, Production of enterotoxin, verotoxin, hemolysin and cytotoxic necrotizing factor by Escherichia coli of intestinal and extraintestinal origin, Folia Microbiologica (Praha) 39(1) (1994) 79-82

[25] J.R. Rhoades, G. Duffy, K. Koutsoumanis, Prevalence and concentration of verocytotoxigenic Escherichia coli, Salmonella enterica and Listeria monocytogenes in the beef production chain: A review, Food Microbiology 26(14) (2009) 357-376

[26] M. Čobeljić, I. Bojić, D. Opačić, Z. Lepšanović, S. Lazić, Prvi dokazani slučaj enterokolitisa u Jugoslaviji uzrokovan enterohemonagijskom Escherichia coli O157, Vojnosanitetski pregled 60(4) (2003) 493-496

[27] S. Lazić, M. Čobeljić, B. Dimić, Verotoksična E.colipatogeni agens koji ugrožava zdravlje životinja i ljudi, Veterinarski Glasnik 59(5-6) (2005) 581-589

[28] Z. Tambur, D. Opačić, R. Doder, M. Marković, Nalaz Escherichia coli i enterokoka u sirevima proizvedenim u domaćinstvu, Veterinarski glasnik 61(1-2) (2007) 109-113

[29] S. Vakanjac, I. Todorović, Subklinički mastitisi ovaca: uzročnici i njihova osetljivost na pojedine antimikrobne lekove,Veterinarski glasnik 64(3-4) (2010) 231-241

[30] V. Kalaba, B. Golić, Ž. Sladojević, D. Kalaba, Incidence of Salmonella infantis in poultry meat and products and the resistance of isolates to antimicrobials, IOP Conf. Series: Earth and Environmental Science 85 (2017)

[31] S. Van Hoorebeke, F. Van Immerseel, F. Haesebrouck, R. Ducatelle, J. Dewulf, The influence of the housing system on Salmonella infections in laying hens: a review, Zoonoses Public Health 58 (2011) 304-11
[32] M. Rašeta, B. Mrdović, V. Janković, Z. Bečkei, B Lakićević, D Vidanović, V. Polaček, Prevalence and antibiotic resistance of Salmonella spp. in meat products, meat preparations and minced meat, IOP Conf. Series: Earth and Environmental Science 85 (2017)

[33] A.L. Stenfors A. Fagerlund, P.E. Granum, From soil to gut: Bacillus cereus and its food poisoning toxins. FEMS Microbiology Reviews 32, (2008), 579-606.

[34] D. Savić, B. Miljković-Selimović, Z. Lepšanović, Z. Tambur, S. Konstantinović, N. Stanković, E. Ristanović, Antimicrobial susceptibility and $\beta$-lactamase production in Bacillus cereus isolates from stool of patients, food and environment samples Vojnosanitetski pregled 73(10) (2016) 904-909.

[35] A. Popović-Vranješ, S. jovanović, M. savuć, M. Krajinović, A. Kasalica, D. Miočinović, J. Kecman, The quality influence of goat milk and technology of production on the characteristic of the goat milk cheese of the Camembert type, Acta Veterinaria 58( 5-6) (2008) 521-529

[36] A.Todorović, B. Kalenjuk, Standardizovana receptura i parametri kvaliteta tradicionalnog pirotskog hleba, Pirotski zbornik 41 (2016) 1-25

[37] S.D. Kocić-Tanackov, G.R. Dimić, Gljive i mikotoksini kontaminenti hrane, Hemijska industrija 67(6) (2013) 639-653

[38] M. Bolechová, K. Benešová, S. Běláková, J. Čáslavský, M. Pospíchalová, R. Mikulíková, Determination of seventeen mycotoxins in barley and malt in the Czech Republic, Food Control 47 (2014) 108-113

[39] D. Milićević, J. Nedeljković-Trailović, Z. Mašić, Mikotoksini $\mathrm{u}$ lancu ishrane - analiza rizika i značaj za javno zdravstvo, Tehnologija mesa55(1) (2014) 22-38

[40] G. Šarić Kanižai, Z. Milaković, V. Krstanovic, Toksičnost Fusarium toksina, Hrvatski časopis za prehrambenu tehnologiju, biotehnologiju i nutricionizam 6(3-4) (2011) 112-116

[41] H.T. Çelik, B. Sarimehmetoğlu, Ö. Küplülü, Aflatoxin M1 contamination in pasteurised milk, Veterinarski arhiv 75 (2005) 57-65

[42] J.W. Bennett, M. Klich, Mycotoxins, Clinical Microbiological Reviews 16(3) (2003) 497-516

[43] D. Mulac, H.U. Humpf, Cytotoxicity and accumulation of ergot alkaloids in human primary cell,Toxicology 282 (2011) 112-121

[44] M.I. Luque, J.J. Córdoba, A. Rodríguez, F. Núñez, M.J. Andrade, Development of a PCR protocol to detect ochratoxin A producing moulds in food products, Food Control 29 (2012) 270-278

[45] M. Snigdha, P. Hariprasad, G. Venkateswaran, Transport via xylem and accumulation of aflatoxin in seeds of groundnut plant, Chemosphere 119 (2015) 524-529

[46] V. Bernáldez, A. Rodríguez, A. Martín, D. Lozano, J.J. Córdoba, Development of a multiplex qPCR method for simultaneous quantification in dry-cured ham of an antifungal-peptide Penicillium chrysogenum strain used as protective culture and aflatoxin-producing moulds, Food Control 36 (2014) 257-265

[47] K.G. Torkar, A. Vengušt, The presence of yeasts, moulds and aflatoxin M1 in raw milk and cheese in Slovenia, Food Control 19(6) (2007) 570-577

[48] S. Kocić-Tanackov, G. Dimić, J. Lević, Lj. Mojović, J. Pejin, Contamination of cakes with toxigenic molds, Journal of Natural Sciences 124 (2012) 213-226

[49] N. Bilandžić, Đ. Božić, M. Đokić, M. Sedak, B.S. Kolanović, 
I. Varenina, Ž. Cvetnić, Assessment of aflatoxin M1 contamination in the milk of four dairy species in Croatia, Food Control 43 (2014) 18-21

[50] F. Caloni, A. Stammati, G. Friggé, I. De Angelis, Aflatoxin M1 absorption and cytotoxicity on human intestinal in vitro model, Toxicon 47, (2006) 409-415

[51] S.M. Polovinski Horvatović, B.V. Jurić, D. Glamočić, The frequency of occurrence of aflatoxin $M 1$ in milk on the territory of Vojvodina, Proceedings of Natural Sciences 116 (2009) 75-80

[52] S.M. Polovinski Horvatović, B.V. Jurić, D. Glamočić, Two year study of incidence of aflatoxin M1 in milk in the region of Serbia, Biotechnology in Animal Husbandry 25 (2009) 713-718

[53] S. Jakšić, B. Abramović, B. Prunić, Ž. Mihaljev, M. ŽivkovBaloš, I. Jajić, V. Despotović, Lj. Bjelica, Incidence of aflatoxins and fumonisins in cereal food from Serbian market, Journal of Agroalimentary Processes and Technologies 17(2) (2011) 108-112

[54] N. Belkacem-Hanfi, I. Fhoula, N. Semmar, A. Guesmi, I. Perraud-Gaime, H.I. Ouzari, A. Boudabous, S. Roussos, Lactic acid bacteria against post-harvest moulds and ochratoxin A isolated from stored wheat, Biological Control 76 (2014) 52-59

[55] L. lacumin, L. Chiesa, D. Boscolo, M. Manzano, C. Cantoni, S. Orlic, G. Comi, Moulds and ochratoxin A on surfaces of artisanal and industrial dry sausages, Food Microbiology 26 (2009) 65-70

[56] M. Škrinjar, Z. Mašić, S.D. Kocić-Tanackov, Fungi and ochratoxin A-Frequency in food and raw materials for their production in Serbia, Proceedings of Natural Sciences 108 (2005) 9-15

[57] S. Stanković, J. Lević, V. Krnjaja, Fumonisin B1 in maize, wheat and barley grain in Serbia, Biotechnology in Animal Husbandry 27(3) (2011) 631-641

[58] N.H. Aziz, F.M. El-fur, A.A.M. Shahin, S.M. Roushy, Control of Fusarium moulds and fumonisin B1 in seeds by gamma-irradiation, Food Control 18(11) (2007) 13371342

[59] J. Huffman, R. Gerber, L. Du, Recent advancement in the biosynthetic mechanism for polyketide-derived mycotoxins, Biopolymers 93 (2010) 764-776

[60] A. Cao, R. Santiago, A.J. Ramos, S. Marín, L.M. Reid, A. Butrón, Environmental factors related to fungal infection and fumonisin accumulation during the development and drying of white maize kernels, International Journal of Food Microbiology 164(1) (2013) 15-22

[61] A. Stepanić, S. Stanković, J. Lević, M. Ivanović, V. Krnjaja, Fusario toxins in wheat grain in Serbia, Pesticides and Phytomedicine 26(4) (2011) 317-323

[62] D. Ivić, A. Domijan, M. Peraica, T. Miličević, B. Cvjetković, Fusarium spp. contamination of wheat, maize, soybean and pea in Croatia, Arhiv za higijenu rada i toksikologiju 60 (2009) 435-442

[63] A. Rodríguez, M.I. Luque, M.J. Andrade, M. Rodríguez, M.A. Asensio, J.J. Córdoba, Development of real-time PCR methods to quantify patulin-producing moulds in food products, Food Microbiology 28(6) (2011) 1190-1199

[64] M.I. Luque, A. Rodríguez, M.J. Andrade, R. Gordillo, M. Rodríguez, J.J. Córdoba, Development of a PCR protocol to detect patulin producing moulds in food products, Food Control 22 (2011) 1831-1838

[65] M. Vaclavikova, Z. Dzuman, O. Lacina, M. Fenclova, Z. Veprikova, M. Zachariasova, J. Hajslova, Monitoring survey of patulin in a variety of fruit-based products using a sensitive UHPLC MS/MS analytical procedure, Food Control 47 (2014) 577-584

[66] C.M. Nagy, S.N. Fejer, L. Berek, J. Molnar, B. Viskolcz, Hydrogen bondings in deoxynivalenol (DON) conformations - a density functional study, Journal of Molecular Structure 726 (2005) 55-59

[67] J. Pleadin, M. Sokolović, N. Perši, M. Zadravec, V. Jaki, A. Vulić, Contamination of maize with deoxynivalenol and zearalenone in Croatia, Food Control 28 (2012) 94-98

[68] S. Mishra, P.D. Dwivedi, H.P. Pandey, M. Das, Role of oxidative stress in Deoxynivalenol induced toxicity, Food and Chemical Toxicology 72 (2014) 20-29

[69] H.J. Van der Fels-Klerx, T.C. de Rijk, Performance evaluation of lateral flow immuno assay test kits for quantification of deoxynivalenol in wheat. Food Control 46 (2014) 390-396

[70] J.J. Pestka, Deoxynivalenol: Toxicity, mechanisms and animal health risks, Animal Feed Science and Technology 137(3-4) (2007) 283-298

[71] I. Jajić, B. Abramović,V. Jurić. S. Krstović, Presence of deoxynivalenon in maize of Vojvodina, Proceedings of Natural Sciences 113, (2007) 135-142

[72] J.G. Pace, M.R. Watts, W.J. Canterbury, T-2 mycotoxin inhibits mitochondrial protein synthesis, Toxicon 26 (1988) $77-85$

[73] J. Goossens, L. De Bock, A. Osselaere, E. Verbrugghe, M. Devreese, K. Boussery, J. Van Bocxlaer, P. De Backer, S. Croubels, The mycotoxin T-2 inhibits hepatic cytochrome P4503A activity in pigs, Food and Chemical Toxicology 57 (2013) 54-56

[74] A. Kuzdraliński, E. Solarska, M. Muszyńska, Deoxynivalenol and zearalenone occurrence in beers analysed by an enzyme-linked immunosorbent assay method, Food Control 29 (2012) 22-24

[75] C. Bouaziz, E.L. Sharaf, O. Dein, E. El Golli, S. AbidEssefi, C. Brenner, C. Lemaire, H. Bacha, Different apoptotic pathways induced by zearalenone, T-2 toxin and ochratoxin $A$ in human hepatoma cells, Toxicology 254 (2008) 19-28

[76] I. Jajić, S. Krstović, B. Perišić, S. Jakšić, V. Bursić, R. Jevtić, B. Abramović,Presence of zearalenone in the most commonly grown wheat cultivars in Serbia, Proceedings of Natural Sciences124 (2013) 101-109

[77] S.D. Kocić-Tanackov, G.R. Dimić, J.T. Lević, D.J. Pejin, J.D. Pejin, I.M. Jajić, Occurrence of potentially toxigenic mould species in fresh salads of different kinds of readyfor-use vegetables, Acta Periodica Tehnologica 41 (2010) 33-45

[78] B. Vitoševič, S. Samrdžić, V. Antonijević, V. Jakovljević, Heavy metals in some imported food products and their potential toxic implications. Medicus 8 (2007) 62-66

[79] M. Živkov Baloš, S. Jakšić, M. Mihaljev, Ž. Čupić, I. Stojanov, J. Apić, M. Jovičin, Mikroelementi i teški metali u mleku krava sa različitih lokaliteta Srbije, Veterinarski glasnik67(5-6) (2013) 317-328

[80] M.C. Talio, M. Alesso, M.G. Acosta, M. Acosta, L.P. Fernández, Sequential determination of lead and cobalt in tap water and foods samples by fluorescence, Talanta 127 (2014) 244-249

[81] S.L.C. Ferreira, V.A. Lemos, L.O.B. Silva, A.F.S. Queiroz, A.S. Souza, E.G.P. da Silva, W.N.L. dos Santos, C.F. das Virgens, Analytical strategies of sample preparation for determination of mercury in food matrices - A review, 
Microchemical Journal 121 (2015) 227-236

[82] S. Janković, D. Nikolić, S. Stefanović, T. Radičević, D. Spirić, Z. Petrović, Procena unosa kadmijuma hranom u Srbiji, Tehnologija mesa 54(2) (2013) 123-129

[83] I.C. Yadav, N.L. Devi, J.H. Syed, Z. Cheng, J. Li, G. Zhang, K.C. Jones, Current status of persistent organic pesticides residues in air, water, and soil, and their possible effect on neighboring countries: A comprehensive review of India, Science of the Total Environment 511 (2015) 123-137

[84] P.C. Abhilash, N. Singh,Pesticide use and application: An Indian scenario, Journal of Hazardous Materials, 165(1-3) (2009) 1-12

[85] D. Trbović, S. Janković, M. Ćirković, D. Nikolić, V. Matekalo-Sverak, V. Đorđević, A. Spirić, Bezbednost i kvalitet mesa nekih slatkovodnih riba u Srbiji, Tehnologija mesa 52(2) (2011) 276-282

[86] S. Janković, B. Antonijević, M. Čurćić, T. Radičević, S. Stefanović, D. Nikolić, V. Ćupić, Assessment of mercury intake associated with fish consumption in Serbia, Tehnologija mesa 53 (1) (2012) 56-61

[87] S.M. Blagojević, S.N. Blagojević, N.D. Pejić, B.A. Begović, S.P. Gajinov, Quality and safety of some commercial spices brands, Acta Periodica Technologica 44 (2013) 1-9

[88] A.A. Perić Grujić, V.V. Procajt, Đ.M. Ristić, Određivanje sadržaja teških metala u čajevima sa tržišta u Beogradu, Srbija, Hemijska industrija 63(5) (2009) 433-436

[89] D. Kostić, S. Mitić, A. Zarubica, M. Mitić, J. Veličković, S. Randjelović, Content of trace metals in medicinal plants and their extracts, Hemijska industrija 65(2) (2011) 165-170
[90] A. Cabrer, M. Casales, M. Yeannes, Physical and chemical changes in anchovy (Engraulis anchoita) flesh during marination, Journal of Aquatic Food Product Technology 11 (2002) 19-31.

[91] T. Tasić, P. Ikonić, Lj. Petrović, A. Mandić, S.Škaljac, M. Jokanović, V. Tomović, B. Šojić, M. Ivić, N. Džinić, Biogenic amines profile of Serbian traditional sausage in relation to raw material and production conditions, Journal of Agricultural Science and Technology 6 (2016) 48-56

[92] B.R. Cvetković, L.L. Pezo, T. Tasić, L. Šarić, Ž. Kevrešan, J. Mastilović, The optimisation of traditional fermentation process of white cabbage (in relation to biogenic amines and polyamines content and microbiological profile), Food chemistry 168 (2015) 471-477.

[93] J.S. Ivanović, J.M. Janjić, S.M. Grbić, J.P. Đorđević, N.M. Glamočlija, T.M. Baltić, M.Ž. Baltić, Effect of modified atmosphere and vacuum packaging conditions on selected chemical and physico-chemical parameters of marinated and salted Atlantic mackerel (Scomber scombrus), Food and Feed Research 43 (2) (2016) 111-118

[94] M. Nosić, Histaminsko trovanje morskom ribom, Croatian journal of food science and technology 2(1) (2010) 26-31.

[95] A. Smajlović, A. Baković, I. Mujezinović , M. Muminović, M Smajlović, O. Kapetanović, S. Hadžijusufović, Utvrđivanje prisustva histamina u uzorcima ribe, Meso 10(3) (2008) 212-214.

Izvod

\section{PREGLED PRISUSTVA NEKIH KONTAMINANATA HRANE NA TERITORIJI REPUBLIKE SRBIJE}

Bojana Danilović, Velibor Potić, Sandra Stamenković, Dragiša Savić

Tehnološki fakultet, Univerzitet u Nišu, Leskovac, Srbija

Kontaminacija hrane predstavlja jedan od vodećih problema u proizvodnji i distribuciji hrane. Mikroorganizmi i njihovi metaboliti predstavljaju najčešće kontaminante. U ovom radu prikazani su slučajevi kontaminacije hrane na teritoriji Republike Srbije. Utvrđeno je da se mikotoksini najčešće mogu naći kao kontaminanti hrane. Među njima najzastupljeniji su zearalenon, aflatoksini, fumonizin i deoksinivalenol.Takođe, velika je zastupljenost kontaminacije mikroorganizmima i to najčešće, bakterijama L. monocytogenes, E. coli, Salmonella spp. i S. aureus. Mikrobna kontaminacija je naročito izražena u mlečnim i proizvodima od mesa. Prisustvo teških metala je detektovano u velikom broju proizvoda ali, u većini slučajeva, ispod dozvoljenih granica. Veće koncentracije olova i žive utvrđene su samo u pojedinim uzorcima čajeva, mleka i ribe. Kako bi se ispunili zahtevi za sigurnošću hrane i internacionalne zakonske regulative, neophodna je stalna analiza, kontrola i prevencija kontaminacije u svim fazama proizvodnje i distribucije hrane.
(PREGLEDNI RAD)

UDK 614.31:615.9:547.67

Ključne reči: kontaminacija hrane, mikroorganizmi, mikotoksini, teški metali 